\title{
CAN BASAL CUTTING BLADE WEAR AFFECT SUGARCANE REGROWTH?
}

\author{
Leonardo Bernache ${ }^{{ }^{*}}$, Danilo Tedesco-Oliveira ${ }^{1}$, Luan P. de Oliveira ${ }^{1}$, Ligia N. Corrêa ${ }^{1}$, \\ Rouverson P. da Silva ${ }^{1}$
}

\author{
${ }^{1 *}$ Corresponding author. Universidade Estadual Paulista "Julio de Mesquita Filho"/ Jaboticabal - SP, Brasil. \\ E-mail: leonardobernacheobj@hotmail.com | ORCID ID: https://orcid.org/0000-0003-4366-7553
}

\section{KEYWORDS}

Mechanized

harvesting, Sugarcane, SPC, Harvester.

\begin{abstract}
Sugarcane harvester cutting blade wear increases ratoon damages and losses, impairing sugarcane regrowth. This study aimed to evaluate the quality of basal cut using ratoon damage and loss indexes and correlating them with effects on sugarcane regrowth. Harvest parameters such as plant height and position, damage and loss indexes, and stem length were evaluated every $30 \mathrm{~min}$, following statistical process control (SPC) assumptions. Blade wear was examined during three harvesting shifts $(0-8 \mathrm{~h}, 8-16 \mathrm{~h}$, and 16-24 h). Sugarcane regrowth was assessed by counting number of tillers and measuring plant height and stem diameter. The second harvesting shift showed better quality in terms of damage and loss indexes, and plant height and stem diameter. Harvesting was considered out of control for parameters such as cutting height, number of tillers, plant height, and stem diameter. On the other side, it was regarded as under control for damage and loss indexes, and plant high and position. The first shift presented peripheral or no damages and weak to medium loss levels, whereas the second and third ones showed extreme damages and medium to strong losses.
\end{abstract}

\section{INTRODUCTION}

Sugarcane mechanized harvesting has provided numerous benefits to the sugarcane industry, highlighting operational capacity, burning and manual harvesting eradication and hence reducing environmental impacts. Moreover, sugarcane harvesters allow farmers adopting operational practices that may interfere with the quality of raw material harvested. Mechanization may also have disadvantages such as reduced quality of raw material (e.g., impurities), skilled labor needs, increased field losses, and ratoon damages (Silva et al., 2008; Ramos et al., 2015).

Basal cutting mechanism may be responsible for part of mechanized harvest losses in sugarcane crops, besides incorporating soil into raw material. Additionally, cutting blade wear increases ratoon damage and loss indexes, which can be worsened as blade cutting angle decreases. As already stated by Cassia et al. (2014), these damages can be worsened as cutting blades wear out. These authors related cutting blade wear to ratoon damages and loss indexes and noted that as cutting-edge wears, i.e. its thickness increases, ratoon damage and loss indexes rise, further impairing sugarcane sprouting and causing the emergence of plantation failures.
Stolf et al. (2016) defined plantation failures as empty spaces without stems in sugarcane rows, which are directly related to yield reductions. According to Toledo et al. (2013), a major importance is given to growing failures during crop implantation, as they have a direct effect during this stage. During sugarcane development, some factors must be controlled such as weeds, drought, underground rhizome pests, trampling of ratoons, thus reducing plant stand failures (Stolf et al., 2016). Toledo et al. (2013) also stated that during harvesting blade types and conditions in harvesters can compromise plant stand due to damages and losses.

Besides basal cut quality, a statistical process control (SPC), a tool of the Statistical Quality Control (SQC), can be helpful in mechanized agricultural operations. SPC can pinpoint failures and suggest improvements for further operations so that operation quality could be increased. A few authors have used SPC with control charts as tools to identify special causes (out-of-control points) in process instability (Noronha et al., 2011, Chioderoli et al., 2012, Zerbato et al. 2013).

Therefore, this study is based on the assumption that the intense use of basal cutting blades increases ratoon damages and losses, hampering the following sugarcane crop

\footnotetext{
${ }^{1}$ Universidade Estadual Paulista "Julio de Mesquita Filho"/ Jaboticabal - SP, Brasil.
} 
development. In this sense, it is believed that impacts caused by the basal cutting mechanism of a harvester during harvest have a relationship with the following crop development.

Based on the above, this study aimed to evaluate the quality of basal cutting mechanism using ratoon damage and loss indexes as a quality indicator and correlating them to further effects on sugarcane regrowth.

\section{MATERIAL AND METHODS}

The experiment was carried out in a sugarcane commercial area during the $2017 / 18$ crop season. The area is located near the city of Ribeirão Preto - SP, Brazil. It has an average altitude of 660 meters and declivity of $14 \%$. Soil water content during the harvest was determined by the gravimetric method $(16.13 \%)$. The soil is classified as clayey ferric Red Latosol with 55\% clay, 34\% silt, and 11\% of total sand, as determined by the granulometric method (Santos et al., 2018).

Planting was carried out in October 2014, using a between-row spacing of $1.5 \mathrm{~m}$. The experiment was installed when the variety SP80-3280 was in the third cut. The evaluated area was $15.7 \mathrm{ha}$, which was assessed for productivity using wagons with load cells. Average productivity was $86 \mathrm{Mg} \mathrm{ha}^{-1}$.

The harvest was made on November 1 and 2, 2017, using an automobile harvester (CASE IH, model A8800) with an engine power of $260 \mathrm{~kW}$ and $1800 \mathrm{rpm}$, and a conveyor belt with a gauge of $1.88 \mathrm{~m}$. Average operating speed was $1.25 \mathrm{~m} \mathrm{~s}^{-1}$. Base cutting system worked at pressures between 10,342 and $13,789 \mathrm{kPa}$, with cutting height of up to $0.05 \mathrm{~m}$ above ground level. Any cut above this limit was considered a stump type loss, according to standards set by the sugarcane mill.

Basal cutting mechanism of the harvester consisted of two discs spaced $0.63 \mathrm{~m}$ apart, from one center to the other. Each disc had five cutting blades and no automatic cutting height control device. "HRC Laser Cladding" brand cutting blades had smooth edges and were made of HSLA (high-strength low-alloy) steel, with a carbon content of 0.05 to $0.25 \%$, to retain conformability and weldability. These blades are 20 to $30 \%$ lighter than carbon steel blades. The blades had five fastening holes positioned from the third hole in the basal cutting system, their initial dimensions were $24.00 \mathrm{~cm}$ in length, $9.00 \mathrm{~cm}$ in width, 1.30 $\mathrm{mm}$ in cutting line thickness, and $594.00 \mathrm{~g}$ average mass.

Cutting blades were evaluated every 8 hours of harvesting, at shift change of operators. From this, three shifts of blade wear intensity were defined: 0 to $8 \mathrm{~h}$ (first shift), 8 to $16 \mathrm{~h}$ (second shift), and 16 to $24 \mathrm{~h}$ (third shift). Yet, during the three shifts, the actual blade working time was only 17 hours, due to several stopovers throughout the process. The same working side of blades was kept in all shifts.

In addition to basal cutting blades, quality indicators related to cutting during harvesting were also assessed, totaling 34 points sampled every 30 minutes. These points were later georeferenced using GPS-receiver (Garmin GPSMAP 60CSx; Garmin International, Inc., Olathe, Kansas, USA).

TABLE 1. Classification of effects of crop posture and position on ratoon impacts. Adapted from Ripolli, T (1996).

\begin{tabular}{ccccc}
\hline & & Classification & Score \\
\hline Posture & Position & Exainst & Extremely unfavorable & 1 \\
Fallen & In favor & Unfavorable & 2 & 3 \\
Lodged & In favor & Unfavorable & Favorable & 4 \\
Fallen & Against & Extremely favorable & 5 \\
Lodged & - & & \\
Erect & & &
\end{tabular}

In addition to posture and position, sugarcane plants were evaluated for stem length, and damage and loss indexes. These variables were assessed in a sample area of $0.75 \mathrm{~m}^{2}$, comprising three metal frames of $0.25 \mathrm{~m}^{2}$, which are commonly used in ratoon evaluations (Figure 2). All the stems collected within the ratoons were evaluated.

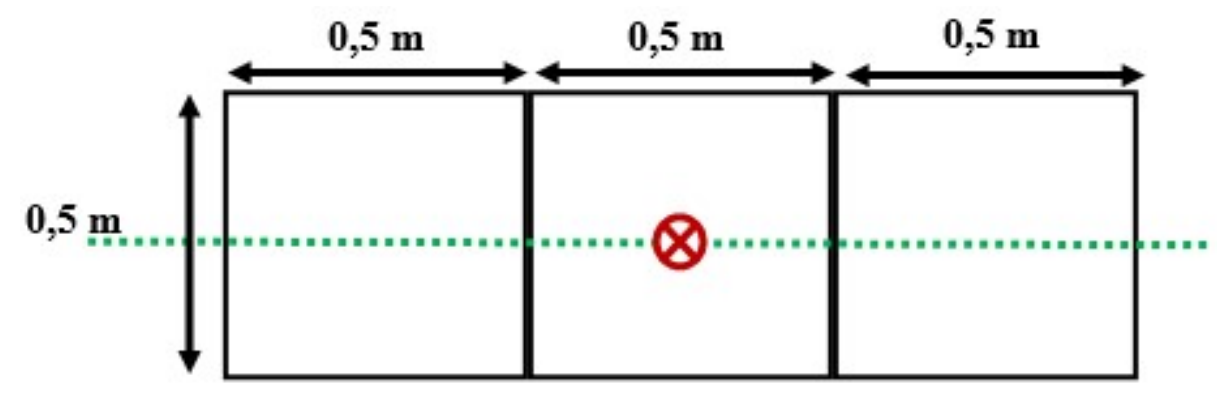

® - Geo-referenced point; " "- " Planting line.

FIGURE 1. Diagram of the sample area. 
Stem length was measured with the aid of a measuring tape, measuring the distance between the stem base and cutting point.

Ratoon damage and loss indexes were assessed by a single person who had already applied the method. Damage indexes (DI) were estimated by adapting the method of Toledo et al., (2013) which ranks damages to ratoons into three levels: without damage $(0.00 \leq \mathrm{DI}<0.33)$, peripheral damage $(0.33 \leq \mathrm{DI} \leq 0.66)$, and extreme damage $(0.66<\mathrm{DI}$ $\leq 1.0)$. After identifying and counting existing damage types, found values were used to generate an index as per [eq. (1)]:

$$
D_{\mathrm{I}=} \frac{\mathrm{W}_{\mathrm{ND}} \cdot \mathrm{N}_{\mathrm{ND}}+W_{\mathrm{PD}} \cdot \mathrm{N}_{\mathrm{PD}}+\mathrm{W}_{\mathrm{ED}} \cdot \mathrm{N}_{\mathrm{ED}}}{\mathrm{N}}
$$

In which:

$$
\text { DI - damage index; }
$$

$\mathrm{W}_{\mathrm{ND}}, \mathrm{W}_{\mathrm{PD}}$, and $\mathrm{W}_{\mathrm{ED}}$ - weights attributed to stems with no damages $(0.00)$, with peripheral damages (0.33), and with extreme damages (1.00), respectively;

$\mathrm{N}_{\mathrm{ND}}, \mathrm{N}_{\mathrm{PD}}$, and $\mathrm{N}_{\mathrm{ED}}$ - number of stems with no damage, with peripheral damage, and extreme damage, respectively,

$\mathrm{N}$ - total number of stems in the ratoon.

Ratoon losses were assessed by a manual force applied to ratoons, estimating their mobilization within the soil and classifying it according to the intensity of force needed to move/tumble stems to the sides (strong, medium, and weak). Based on this classification, loss index (LI) was classified into three levels: strong $(0.66<\mathrm{LI} \leq 1.0)$, medium $(0.33 \leq \mathrm{LI} \leq 0.66)$, and weak $(0.00 \leq \mathrm{LI}<0.33)$, based on the method of Voltarelli et al. (2015), so that the greater the mobilization, the greater the loss of ratoons. Loss index was estimated as per [eq. (2)]:

$$
\mathrm{i}_{\mathrm{A}=} \frac{\mathrm{W}_{\mathrm{WS}} \cdot \mathrm{N}_{\mathrm{WS}}+\mathrm{W}_{M S} \cdot \mathrm{N}_{\mathrm{MS}}+\mathrm{W}_{S S} \cdot \mathrm{N}_{\mathrm{SS}}}{\mathrm{N}}
$$

In which:

\section{LI - loss index;}

$\mathrm{W}_{\mathrm{ws}}, \mathrm{W}_{\mathrm{MS}}$, and $\mathrm{W}_{\mathrm{SS}}$ - weights attributed to stems with weak (0.00), mean $(0.33)$, and strong $(1,00)$ losses, respectively;

$\mathrm{N}_{\mathrm{WS}}, \mathrm{N}_{\mathrm{MS}}$, and $\mathrm{N}_{\mathrm{SS}}$ - number of stems with weak, medium, and strong losses, respectively,

$\mathrm{N}$ - total number of stems in the ratoon.

At 78 days after harvesting, when canopy closed, plant regrowth was evaluated using a GPS device (Garmin GPSMAP 60CSx; Garmin International, Inc., Olathe, Kansas, USA) to locate the ratoons evaluated during harvest. In this evaluation, the analyzed variables were plant height and diameter, and number of tillers. The sample area was the same as previously determined $\left(0.75 \mathrm{~m}^{2}\right)$.

Stem height and diameter were determined in 10 plants per sampling points, with the aid of a measuring tape and pachymeter, respectively. While for the quality index, the number of tillers were counted using all stems found within the sample area.
The experimental design followed the assumptions of statistical quality control (SQC), aiming to evaluate the process over time. Continuous variables were initially analyzed using descriptive statistics using central tendency (arithmetic mean and median), position (amplitude, standard deviation, and coefficient of variation). Later, data were submitted to the Ryan-Joiner normality test, which is similar to the Shapiro-Wilk test.

The Minitab® ${ }^{\circledR}$ software was used to calculate Pearson's correlation coefficient at $5 \%$ probability, classifying them according to the one proposed by Callegari-Jacques (2003) into: weak $(|0.00|<<0.30 \mid)$, moderate $(0.30 \mid \leq \mathrm{r}<.60)$, strong $(|0.60| \leq \mathrm{r}<.090 \mid)$, and very strong $(|0.90| \leq \mathrm{r}<1,00 \mid)$.

The same software was used to evaluate process variability using control charts of individual values. These charts present central lines (overall mean) as well as upper and lower control limits (ULC and LCL). Such control limits allow us to infer whether there are variations in results due to uncontrolled causes in the process (special causes). These variations are estimated using the standard deviation of variables, as shown in eqs (3) and (4):

$$
\begin{aligned}
& \mathrm{ULC}=\bar{x}+3 \sigma \\
& \mathrm{LCL}=\bar{x}-3 \sigma
\end{aligned}
$$

In which:

ULC and LCL: upper and lower control limit;

$\bar{x}$ : general mean of the variable,

$\sigma:$ standard deviation.

To determine damage index and loss indexes, specific control limits (USL $=0.66$, and LSL $=0.33$ ) were also established for evaluation of the quality of operation based on these limits. Thus, for points located below LSL, ratoon damages and losses were considered of low impact (nondamaged and weakly disturbed), while points located between LSL and USL were deemed medium impact (peripheral damages and medium loss), and points above USL were regarded high impact (extreme damages and high loss).

Variability in plant posture and position was assessed by attribute control charts using the "chart c", which is indicated for investigating discrete data when assessing total number of "defects" (posture or position) on a unit of the product (ratoon).

\section{RESULTS AND DISCUSSION}

The descriptive analysis results (Table 2) showed high coefficients of variation (CVs) for all parameters; hence, data presented high or very high dispersion (Pimentel Gomes \& Garcia, 2002). High dispersion for stem length data can be measured by the distance between mean and median, high amplitudes, standard deviations, and very high CVs. For the other parameters but damage index and loss indexes, amplitudes and CVs were high (between 20\% and $30 \%$ ), i.e. non-normal distributions. High data variability is common in mechanized sugarcane harvesting. Unfortunately, it cannot be completely eliminated since sugarcane harvester operating performance is influenced by several systemically interrelated parameters (Benedini \& Conde, 2008; Reis et al., 2015). Despite the high CVs, damage and loss indexes showed normal probability distribution according to the Ryan-Joiner normality test. 
TABLE 2. Descriptive analysis and normality test of quality indicators.

\begin{tabular}{lccccccc}
\hline Quality indicator & $\overline{\mathrm{X}}$ & $\mathrm{M}$ & $\mathrm{A}$ & $\mathrm{S}$ & $\mathrm{CV}$ & $\mathrm{RJ}$ & $\mathrm{p}$-Value \\
\hline Stem length & 9.49 & 8.07 & 28.10 & 5.63 & 59.28 & $0.870^{\mathrm{A}}$ & $<0.010$ \\
Damage index & 0.75 & 0.80 & 0.70 & 0.21 & 28.36 & $0.976^{\mathrm{N}}$ & $>0.100$ \\
Loss index & 0.49 & 0.49 & 0.89 & 0.25 & 51.97 & $0.994^{\mathrm{N}}$ & $>0.100$ \\
Tiller number & 32.97 & 32.50 & 54.00 & 9.42 & 28.57 & $0.956^{\mathrm{A}}$ & 0.017 \\
Height after regrowth & 35.11 & 36.45 & 53.50 & 9.19 & 26.17 & $0.953^{\mathrm{A}}$ & $<0.010$ \\
Diameter after regrowth & 18.63 & 18.70 & 24.50 & 4.20 & 22.52 & $0.863^{\mathrm{A}}$ & $<0.010$ \\
\hline
\end{tabular}

$\bar{X}$ - general average; $\mathrm{M}$ - median; A - total amplitude; $\sigma$ - standard deviation; CV (\%) - coefficient of variation; RJ - Ryan-Joiner normality test; $\mathrm{p}$-value - probability distribution $(\mathrm{p}>0.05)$;

Regarding sugarcane posture and position (Figure 2), 38\% of the observations (13 points) were classified as unfavorable or extremely unfavorable for mechanized harvesting operation. It was attributed to the fact that, when harvesting a row, the harvester pushes plants over adjacent rows, falling to the opposite direction of the machine's return path, given the row divider. Thus, a sugarcane crop can be classified as favorable to harvest initially but, after harvester passing, this condition can be changed by the action of row dividers. Although Voltarelli et al. (2015) and Noronha et al. (2011) stated that sugarcane upright position is ideal for mechanized harvesting, these authors did not assess field lodging level. Given the sugarcane harvester mechanism, another factor favoring ratoon damages and losses is plant position in relation to the harvester path. If positioned against harvester movement direction, improper harvesting conditions may be generated.

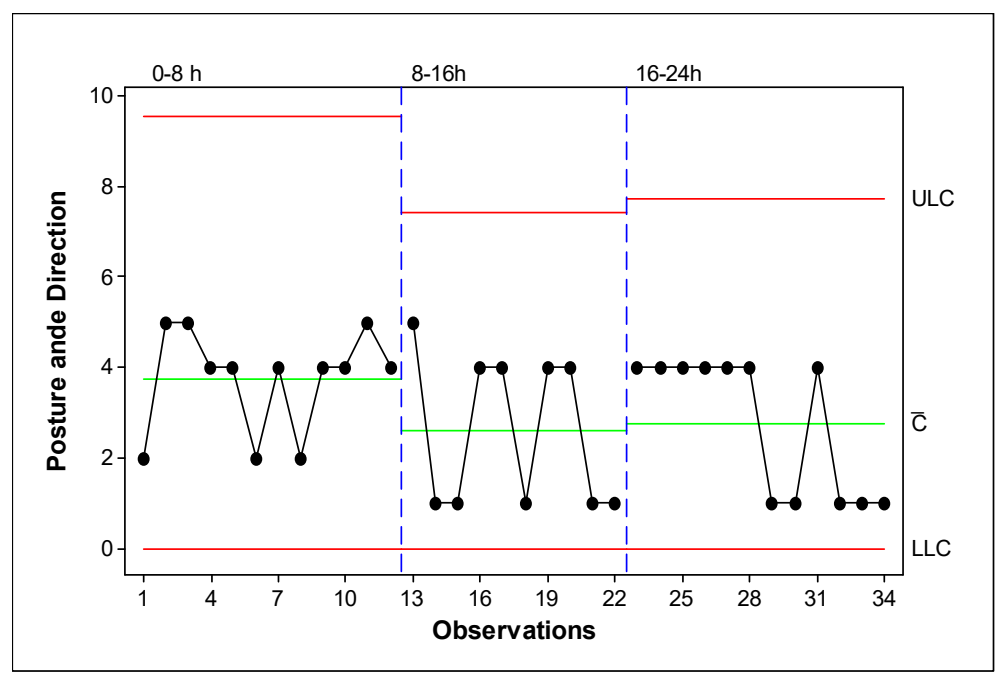

FIGURE 2. Attribute control chart "c-chart" for ratings related to posture and direction of harvesting travel. ULC - upper limit of control; LLC - lower limit of control; $\mathrm{C}^{-}$. - arithmetic mean of individual values.

Ratoon stem lengths (Figure 3) denotes that the mean harvesting height was above that set in the machine for the operation $(0.05 \mathrm{~m})$, with 4 points below the specific limit of control (SLC). These results are unfavorable for harvesting at the mill in question since all stems above the (SLC) are counted as "stump" losses. This characterizes low-quality harvest, with increasing losses of raw material in the field (higher stem sucrose levels).

The quality control chart for stem length showed the instability of the harvesting process due to the points above the upper limit of control (ULC). These points occur due to special causes attributed to labor, environment, machine, method, measurement, and raw material. Voltarelli et al. (2017) reported that machine and labor are more related to harvest height quality. Besides these, we noticed that raw material and environment may also be related to special causes. Sugarcane posture is a quality index intrinsically related to raw material (fiber content and sugarcane tons per hectare - STH) and environment (climatic conditions). Yet sugarcane positioning can be both related to the environment and to "natural" lodging, and also to machine factor due to the action of row dividers during the harvest, which can push the adjacent line of sugarcane not harvested yet by changing its direction. 


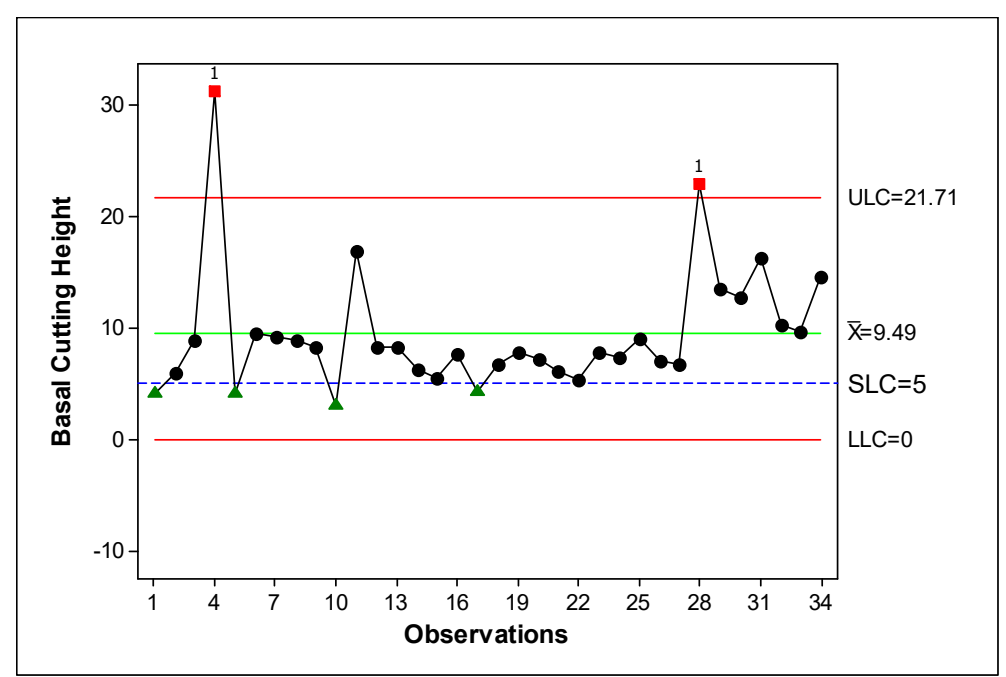

FIGURE 3. Control chart for individual basal cutting height. ULC - upper limit of control; LLC - lower limit of control; $\bar{x}$ arithmetic mean of individual values; SLC - Specific limit of control.

According to the damage index control chart (Figure $4)$, the harvesting process was stable on all shifts. However, on the second shift (8-16 h), variability was lower compared to the other ones, evidenced by a major proximity between upper and lower control limits.

By assessing each shift in detail, some damage index patterns could be defined. On the first shift, points at all three damage levels (no damage, peripheral, and extreme damage) were observed, with 59\% of them below the SLC.
It means predominance of undamaged stems or stems with peripheral damages, which is ideal for mechanized harvesting. Damage indexes rose above the SLC in 100 and $75 \%$ of the sampled points on the second and third shifts, respectively. These high levels indicate the effect of blade wear on ratoon damage. According to Salvi et al. (2007), it can be a problem for sugarcane crops since damaged ratoons are pathways for the entry of pests and diseases, reducing productive potential in the following seasons.

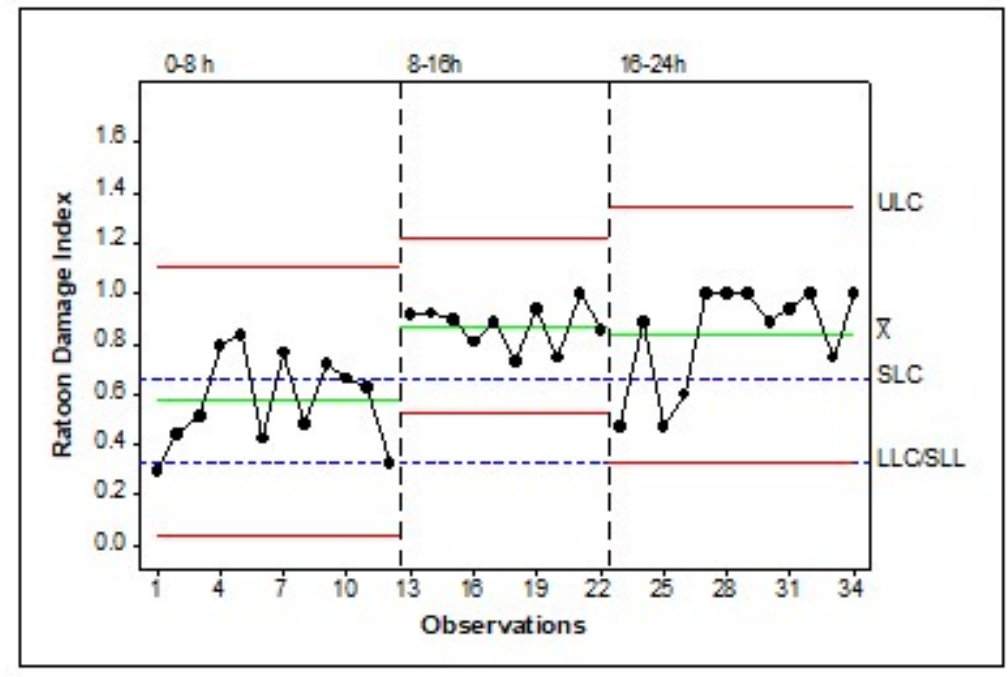

FIGURE 4. Individual value control chart for average ratoon damage index per harvesting shift of the harvester. ULC - upper limit of control; LLC - lower limit of control; SLC - specific upper limit; SLL - specific lower limit; $\bar{x}$ - arithmetic mean of individual values.

As for damage indices, loss index control chart (Figure 5) showed no out-of-control points; therefore, harvesting was stable for these indexes, i.e. process variations are due only to the action of common causes (random). On the first shift, 59\% of the points evaluated were below the SLL, with only one point above the SLC. On the second, $50 \%$ of the points were above the SLC, while the other $50 \%$ were within the specific limits (SLL and SLC), and no points below the SLL. Finally, on the last,
$41 \%$ of the points showed extreme loss indexes, and only $25 \%$ presented indexes below the SLL.

When comparing points with a cut height below the SLC, which is ideal for the mill, low loss indexes were observed. Our findings corroborate those of Cassia et al. (2014), who noticed a proportional increase in ratoon damage and loss indexes as blade wear occurs and hence affecting sugarcane regrowth. 


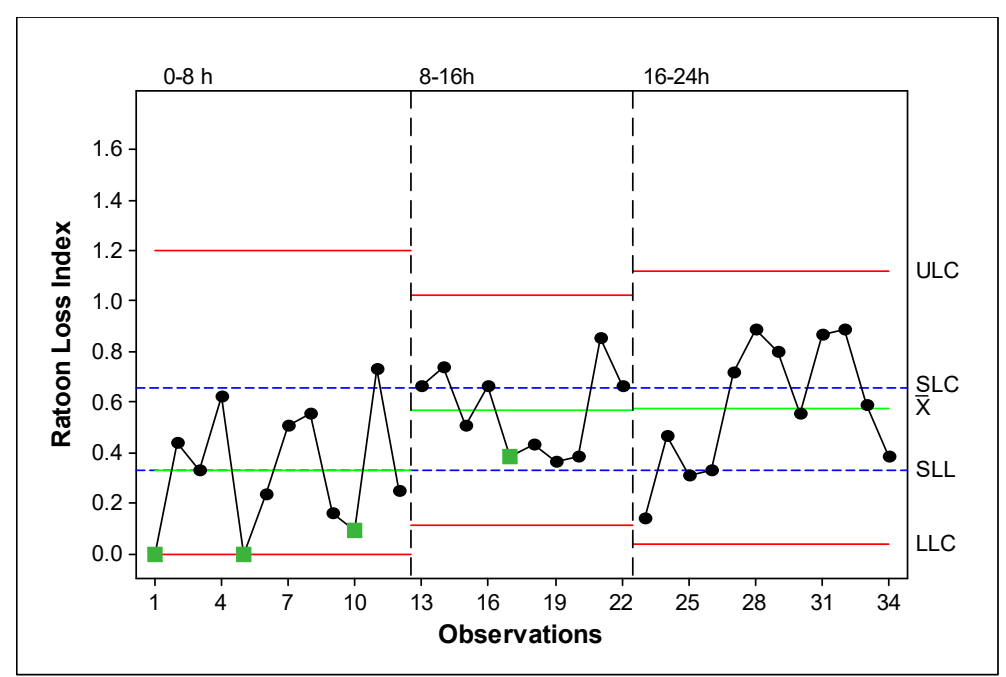

FIGURE 5. Individual value control chart for average ratoon loss index per harvesting shift of the harvester. ULC - upper limit of control; LLC - lower control limit; SLC - specific upper limit; SLL - specific lower limit; $\bar{x}$ - arithmetic mean of individual values; - points where cutting height was equal to or less than $0.05 \mathrm{~m}$.

It is noteworthy that both control charts (Figures 4 and 5) have shown harvest variability decrease on the second harvesting shift compared to the others. This may be related to marked blade wear during initial use, which is less intense during the process.

For tiller number, control chart (Figure 6) shows only one point out of the control limit on the first shift. It can be explained by an extensive stand failure in the field, which encompassed the entire sample area $(1.5 \mathrm{~m})$. By contrast, on the other shifts, special causes had no influence on sugarcane development. Likewise, only one out-ofcontrol point occurred for other regrowth-related parameters such as plant height and stem diameter.

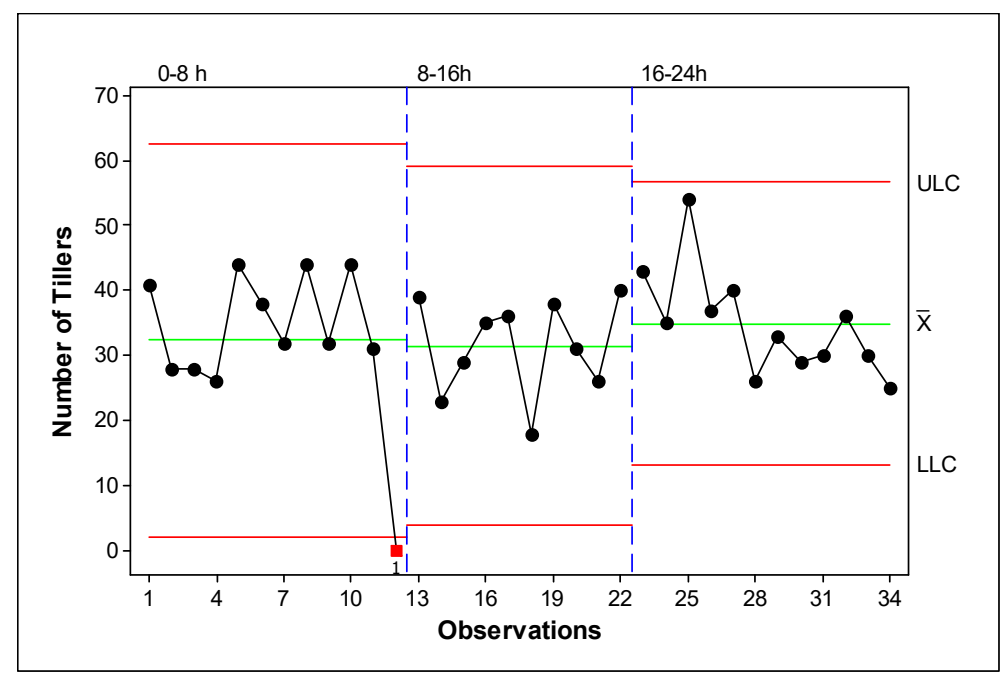

FIGURE 6. Individual value control chart for average number of tillers at 70 days after harvest. ULC - upper limit of control; LLC - lower limit of control; $\bar{x}$ - arithmetic mean of individual values.

As shown in Figure 7, plant height behaved differently from tiller number. On the second shift, process variability was lower than in the others. Another relevant factor is the high variability on the third shift, which shows the impact of blade wear on ratoons over the harvesting time. 


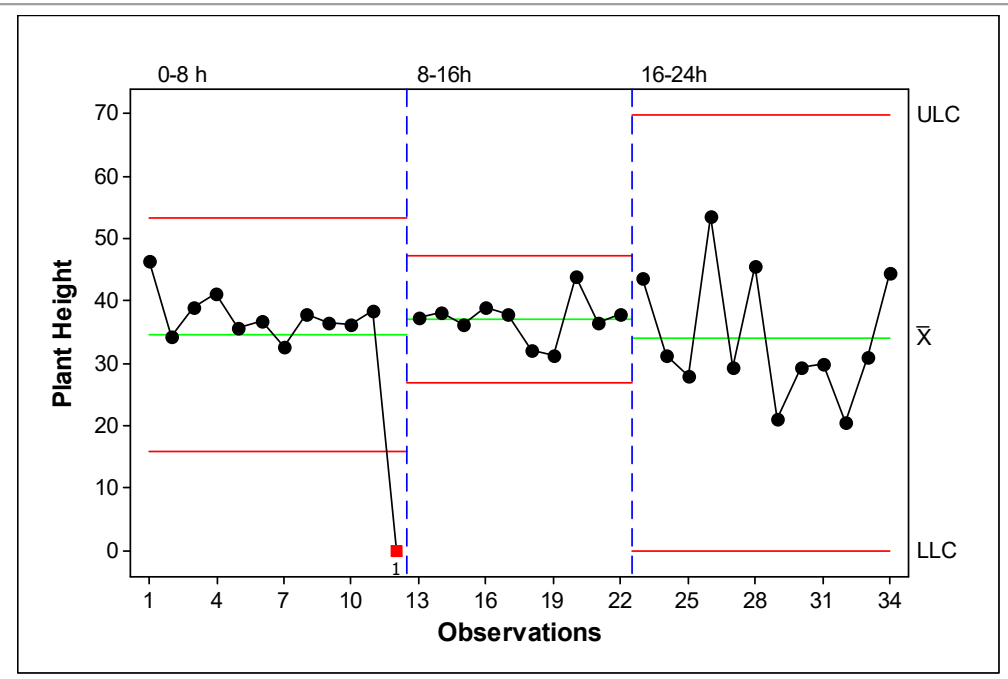

FIGURE 7. Individual value control chart for average plant height (in centimeters) at 78 days after harvest. ULC - upper limit of control; LLC - lower limit of control; $\bar{x}$ - arithmetic mean of individual values.

Figure 8 reveals that plant diameter had similar behavior to the previous one, i.e. lower variability on the second shift. It shows smaller impacts of blade wear after 8 hours of harvesting. Shifts 1 and 3 presented a high variability; in other words, the effect of cutting blade wear had a strong relationship with the impacts on sugarcane sprouting.

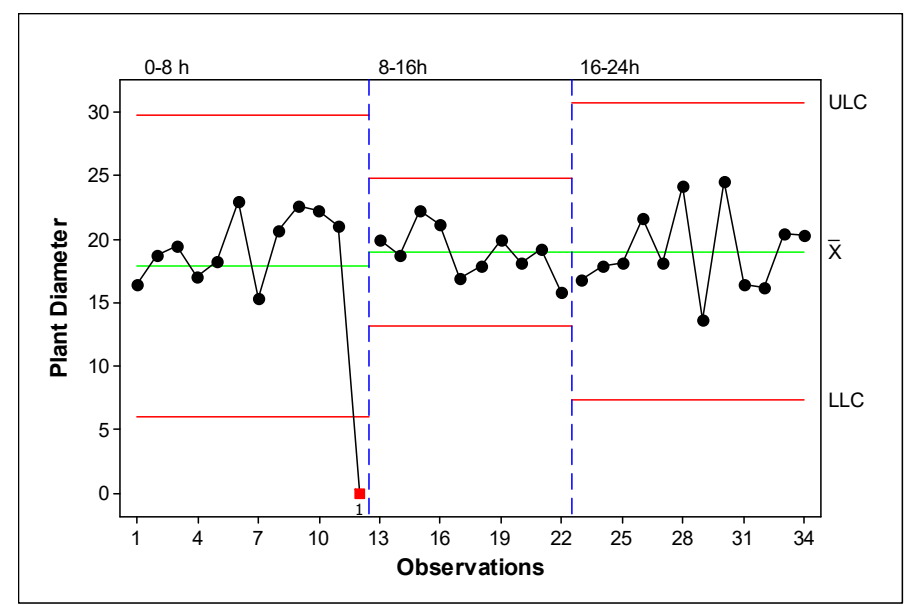

FIGURE 8. Individual value control chart for average plant diameter (in centimeters) at 78 days after harvest. ULC - upper limit of control; LLC - lower limit of control; $\bar{x}$ - arithmetic mean of individual values.

TABLE 3. DATA CORRELATION BY PEARSON'S CORRELATION COEFFICIENT.

\begin{tabular}{llllll}
\hline Parameter & Stem length & Damage index & Loss index & Tiller number & Height \\
\hline Damage index & $0.210^{\mathrm{ns}}$ & - & - & - & - \\
Loss index & $0.443^{*}$ & $0.633^{*}$ & - & - & - \\
Tiller number & $-0.259^{\mathrm{ns}}$ & $-0.055^{\mathrm{ns}}$ & $-0.222^{\mathrm{ns}}$ & - & - \\
Height & $0.058^{\mathrm{ns}}$ & $-0.003^{\mathrm{ns}}$ & $-0.139^{\mathrm{ns}}$ & $0.379^{*}$ & - \\
Diameter & $0.071^{\mathrm{ns}}$ & $0.232^{\mathrm{ns}}$ & $0.065^{\mathrm{ns}}$ & $0.434^{*}$ & $0.673^{*}$ \\
\hline
\end{tabular}

Table 3 reveals a moderate positive correlation of loss index with stem length and a strong and positive one with damage index. Number of tillers had moderate positive correlations with plant height and stem diameter, and plant height showed a strong positive correlation with stem diameter. Such correlations indicate that when one variable is changed the other changes proportionally; however, linear regressions could not be fit to describe these relationships. Thus, despite the moderate and strong correlations, these variables cannot be explained linearly by each other.
Loss indexes were correlated with stem length. This may be explained by the non-use of automatic cutting height control during harvesting; thus, stem length can be associated with ratoon loss by a higher torque effect on ratoon base. Loss indexes also presented a linear correlation with damage indexes, showing the good foundation of the method, given the relationship between ratoon damage and loss indexes. Again, despite the correlations, these variables cannot be explained linearly by each other. 


\section{CONCLUSIONS}

Harvester basal-cutting blade wear does not affect sugarcane regrowth; however, as this wear intensifies, ratoon damages and losses become more pronounced. This is evidenced by a high relationship between extreme damages and strong losses.

In the following harvest seasons, the blade wear factor becomes more related to sugarcane regrowth, negatively impacting crop development. Therefore, blade wear effect must be monitored throughout the entire sugarcane cycle, from the first cut to the end of the cycle ( 5 or 6 years).

\section{REFERENCES}

Benedini MS, Conde AJ (2008) Sistematização de área para colheita mecanizada da cana-de-açúcar. Revista Coplana (53):23-25. Available:

http:/www.coplana.com/gxpfiles/ws001/design/RevistaCo plana/2008/Novembro/pag23-24-25.pdf.

Callegari-Jacques SM (2003) Bioestatística: princípios e aplicações. Porto Alegre, Artmed, 365 p.

Cassia MT, Silva RP, Paixão CSS, Bertonha RS, Cavichioli FA (2014) Desgaste das lâminas do corte basal na qualidade da colheita mecanizada de cana-de-açúcar. Ciência Rural 44(6):987-993. DOI:

http://dx.doi.org/10.1590/S0103-84782014000600006

Chioderoli CA, Silva RP, Noronha RHF, Cassia MT, Santos EP (2012) Perdas de grãos e distribuição de palha na colheita mecanizada de soja. Bragantia 71(1):112-121. DOI: http://dx.doi.org/10.1590/S0006-

87052012005000003

Santos HG, Jacomine PKT, Anjos LHC, OLIVEIRA VA, de; Lumbreras JF, Coelho MR, Almeida JA, Araujo Filho JC, Oliveira JB, Cunha TJF. Sistema Brasileiro de Classificação de Solos. 5. ed. rev. e ampl. Brasília, DF: Embrapa, 2018.

Noronha RHF, Silva RP, Chioderoli CA, Santos EP, Cassia MT (2011) Controle estatístico aplicado ao processo de colheita mecanizada diurna e noturna de canade-açúcar. Bragantia 70(4): 931-938. DOI: https://dx.doi.org/10.1590/S0006-87052011000400028

Pimentel Gomes F, Garcia CH (2002) Estatística aplicada a experimentos agronômicos e florestais: exposição com exemplos e orientações para uso de aplicativos. Piracicaba, 11 ed. 309 p.
Ramos CRG, Lanças KP, Sandi J, Lyra GA, Millani TM (2015) Qualidade do corte dos rebolos na colheita mecanizada de cana-de-açúcar em diferentes condições operacionais. Energia na Agricultura 30(3):217-224. DOI: https://doi.org/10.17224/EnergAgric.2015v30n3p217-224

Reis GN, Voltarelli M, Silva RP, Toledo A, Lopes A (2015) Quality harvesting in the basement cut of sugarcane soil management systems. Comunicata Scientiae 6:143-153.

Ripoli TCC (1996) Ensaio \& certificação de máquinas para colheita de cana-de-açúcar. In: MIALHE, L.G. Máquinas agrícolas: ensaios \& certificação. Piracicaba, Fundação de Estudos “Luiz de Queiroz”, cap.13, p.635-673.

Salvi JV, Matos MA, Milan M (2007) Avaliação do desempenho de dispositivo de corte de base de colhedora de cana-de-açúcar. Engenharia Agrícola 27(1):201-209. DOI: https://dx.doi.org/10.1590/S010069162007000100014

Silva RP, Corrêa CF, Cortez JW, Furlani CEA (2008) Controle estatístico aplicado ao processo de colheita mecanizada de cana-de-açúcar. Engenharia Agrícola 28:292-304. DOI: http://dx.doi.org/10.1590/S010069162008000200010

Stolf R, Garcia TB, Neris LO, Trindade Junior O, Reichardt K (2016) Avaliação de falhas em cana-de-açúcar segundo método de Stolf utilizando imagens aéreas de alta precisão obtidas por VANT. Revista STAB 34:32-39.

Toledo A, Silva RP, Furlani CEA (2013) Quality of cut and basecutter blade configuration for the mechanized harvest of green sugarcane. Scientia Agricola 70(6):384389. DOI: https://dx.doi.org/10.1590/S010390162013000600002

Voltarelli MA, Silva RP, Cassia MT, Ortiz DF, Torres, LS (2015) Qualidade do corte basal de cana-de-açúcar utilizando-se de três modelos de lâminas. Engenharia Agrícola 35(3):528-541.

DOI:https://dx.doi.org/10.1590/1809-4430-

Eng.Agric.v35n3p528-541/2015

Voltarelli MA, Silva RP, Cassia MT, João Guilherme Muzetti Daloia JGM, Paixão CSS (2017) Qualidade do corte basal de cana-de-açúcar efetuado por lâminas de diferentes angulações e revestimentos. Revista Ciência Agronômica 48(3):438-447. DOI: https://dx.doi.org/10.5935/1806-6690.20170051

Zerbato C, Cavichioli FA, Raveli MB, Marrafon M, Silva RP (2013) Controle estatístico de processo aplicado à colheita mecanizada de milho. Engenharia na agricultura 21(3):261-270. DOI: https://dx.doi.org/10.13083/14143984.v21n03a05 